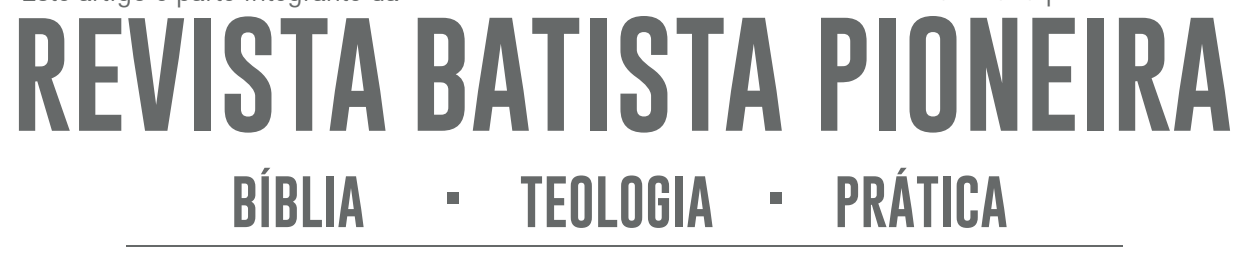

ONLINE ISSN 2316-686X - IMPRESSO ISSN 2316-462X

Vol. 8 - n. 2 - Dezembro| 2019

\title{
AS DIFERENÇAS DOUTRINÁRIAS DO CALVINISMO E DO ARMINIANISMO
}

\section{The doctrinary differences of Calvinism and Arminianism}

Me. Jeverson Nascimento ${ }^{1}$

\section{RESUMO}

O presente artigo tem o objetivo de apresentar reflexões sobre as diferenças doutrinárias calvinista (defendida pelo Calvinismo), e arminiana (sob o ponto de vista do Arminianismo), conceituando-as, abordando as principais doutrinas que embasam essas linhas teológicas, suas divergências, seus principais seguidores e reflexões sobre as mesmas. O Calvinismo leva este nome por causa do seu precursor John Calvino, e suas principais doutrinas são Depravação Total, Eleição Incondicional, Expiação Limitada, Graça Irresistível e Perseverança dos Santos. Já o Arminianismo foi o nome dado à linha teológica e doutrinária advinda dos seguidores de Jacob Arminius, cuja principais doutrinas são: Livre-Arbítrio, Predestinação Condicional, Expiação

\footnotetext{
${ }^{1}$ Possui Licenciatura em Filosofia - Faculdades Entre Rios de Piauí (2016) e Graduação em Teologia pelo Centro de Ensino Superior de Maringá (2014). Mestre em Teologia - Faculdades Batista do Paraná (2017). Atualmente é professor visitante do Centro de Teologia de Santa Catarina. Tem experiência na área de Teologia, com ênfase em Pratica ministeriais, atuando principalmente nos seguintes temas: divergências e convergências, Deus, métodos de interpretação bíblica, bíblia sagrada e filosofia e teologia pratica.E-mail: prjeverson@gmail.com.
} 
Universal, A Graça pode ser impedida e Decair da Graça. As divergências entre estas duas linhas teológicas circulam entre essas principais doutrinas apresentadas e na conceituação de cada uma delas. Conclui-se que tanto o Calvinismo quanto o Arminianismo constituem dois sistemas teológicos que tentam explicar a relação entre a soberania de Deus e a responsabilidade humana em relação à salvação e que ambos estão fundamentados em textos bíblicos, fato que gera divergências desde 1610 e ainda reflete na vida cristã da sociedade.

Palavras-chaves: Diferenças doutrinárias. Calvinismo. Arminianismo.

\section{ABSTRACT}

The present article has the objective of presenting reflections on the doctrinal differences Calvinism (defended by Calvinism), and Arminian (from the point of view of Arminianism), conceptualizing them, addressing the main doctrines that support these theological lines, their divergences, their main followers and reflections on them. Calvinism bears this name because of its forerunner John Calvin, and its main doctrines are Total Depravity, Unconditional Election, Limited Atonement, Irresistible Grace and Perseverance of the Saints. Already Arminianism was the name given to the theological and doctrinal line coming from the followers of Jacob Arminius, whose main doctrines are: Free Will, Conditional Predestination, Universal Atonement, Grace can be prevented and Decay of Grace. The divergences between these two lines theological doctrines circulate between these main doctrines presented and in the conceptualization of each of them. It is concluded that both Calvinism and Arminianism constitute two theological systems that attempt to explain the relationship between God's sovereignty and human responsibility for salvation and that both are based on biblical texts, a fact that has generated divergences since 1610 and still reflects in the Christian life of society.

Keywords: Doctrinal differences. Calvinism. Arminianism.

\section{INTRODUÇ̄̃̃O}

Segundo Berkhof (1992), nos dias atuais, cada religião oferece um tipo diferente de salvação e possui sua própria soteriologia. Algumas enfatizam o relacionamento do homem em unidade com Deus, outras o aprimoramento 
do conhecimento humano como forma de se obter a salvação. O Calvinismo apresenta as doutrinas da Depravação Total, Eleição Incondicional, Expiação Limitada, Graça Irresistível e Perseverança dos Santos.

Já o Arminianismo contempla doutrinas opostas: Livre-Arbítrio, Predestinação Condicional, Expiação Universal, A Graça pode ser impedida e Decair da Graça. Diante disso, como apresentar reflexões sobre a soteriologia calvinista e a soteriologia arminiana? ${ }^{2}$

O objetivo deste artigo é refletir sobre as diferenças doutrinárias calvinistas e arminianas, conhecendo as principais doutrinas que embasam essas duas linhas teológicas; e abordando suas divergências e os seus reflexos na atualidade.

Este estudo é de caráter bibliográfico e permite afirmar que os cristãos buscam a salvação. Frequentemente, ouve-se a frase: "Hoje eu apresentei o plano da salvação para um homem hoje”. Dessa forma, torna-se evidente a existência de um plano para a salvação, fazendo-se necessária uma reflexão mais aprofundada sobre essa expressão.

O primeiro tópico trata sobre Calvino, seu nascimento, sua história, e seus principais discípulos. O segundo tópico trata sobre Armínio, seu nascimento, sua história, e seus principais discípulos. E o terceiro tópico traz uma reflexão sobre as diferenças doutrinárias dessas duas linhas teológicas.

\section{CALVINO: SEU NASCIMENTO, SUA HISTÓRIA E SEUS PRINCIPAIS DISCIPULOS}

A expressão "Calvinismo" vem do termo Calvino e foi usada pela primeira vez em 1552, numa carta do pastor luterano Joachim Westphal, de Hamburgo. O calvinismo também é conhecido como Fé Reformada, Confissão Reformada ou Teologia Reformada, se caracterizando tanto como movimento religioso protestante, quanto como ideologia sociocultural com raízes na Reforma Protestante iniciada por João Calvino, em Genebra. ${ }^{3}$

João Calvino (1509-1564) nasceu em Noyon, na região da Picardia, no

\footnotetext{
${ }^{2}$ BERKHOF, Louis. A história das doutrinas cristãs. São Paulo: Publicações Evangélicas Selecionadas, 1992, p. 10.

${ }^{3}$ SILVESTRE, Armando. Calvino: o potencial revolucionário de um pensamento. São Paulo: Vida, 2009, p. 16.
} 
Norte da França, no dia 10 de julho de 1509. Ficou órfão de mãe aos seis anos de idade, sendo confiado aos cuidados de um aristocrata amigo da família. Ainda adolescente foi enviado para a Universidade de Paris para estudar Teologia. Em Paris, tomou contato com as ideias de Martinho Lutero. Em 1529, em obediência ao pai, trocou Paris por Orléans, e a Teologia pelo Direito. Depois de formado voltou a Paris e à Teologia. Começou uma fase de intensa colaboração com o reitor da Universidade de Paris, Nicolas Cop. Ao inserir trechos inteiros de Lutero em um discurso de reitor, foi acusado de herege. ${ }^{4}$

João Calvino aderiu ao protestantismo entre 1532 e 1536, tendo passado por Genebra, onde veio a ser considerado o grande "reformador universal". Participou do Conselho da Cidade, em assuntos eclesiásticos, mesmo sem poder decidir, pois era estrangeiro, mas no qual exerceu grande influência a respeito de seu governo civil, ajudando a elaborar leis, fundando a Academia de Genebra e tornando Genebra o principal centro protestante da Europa. Ajudou a estabelecer grandes reformas na Igreja na cidade, onde trabalhou até a sua morte, em 27/05/1564, deixando um legado imenso e muitas obras publicadas. ${ }^{5}$

Em 1536, após redigir em latim, "Instituições da Religião Cristã”, em que reuniu as bases para o conjunto das doutrinas do Calvinismo, foi perseguido e teve que abandonar a capital francesa. Em 1538, depois de ter frustradas suas tentativas de instaurar um governo teocrático, Calvino foi expulso de Genebra. Em setembro de 1547, retorna à Genebra a pedido das autoridades, para impedir a tentativa do cardeal de restaurar o catolicismo. Realiza na íntegra o governo civil, que tornou supérflua a hierarquia eclesiástica. Estabeleceu leis, abriu escolas e estimulou o comércio exterior, pregou e ensinou o calvinismo. ${ }^{6}$

João Calvino estabeleceu diversas reformas na Igreja, eliminou o ritual e a música instrumental da missa, despiu as igrejas de vitrais, quadros e imagens, reduziu o culto a um sermão entre quatro paredes nuas. Aboliu as comemorações da Páscoa e do Natal e apagou todos os vestígios do sistema episcopal. Faleceu em Genebra, na Suíça, no dia 27 de maio de $1564 .^{7}$

Do século XVI até os dias atuais, tem-se espalhado por toda a terra o

\footnotetext{
${ }^{4}$ SILVESTRE, 2009 , p. 7.

${ }^{5}$ SILVESTRE, 2009, p. 18.

${ }^{6}$ SILVESTRE, 2009, p. 7-8.

${ }^{7}$ SILVESTRE, 2009, p. 10.
} 
cristianismo de orientação calvinista, com muitos seguidores de sua teologia. Na Europa Ocidental, os calvinistas foram chamados de huguenotes (França), presbiterianos (Escócia), puritanos (Inglaterra) e protestantes (Holanda). A Fé Reformada leva o nome de Calvinismo por ter sido Calvino o seu principal expoente. Calvinismo é resultado de uma evolução independente das ideias protestantes que nasceram sob a influência de Martinho Lutero.

O calvinismo é compreendido como o sistema teológico das Igrejas Reformadas, cuja expressão doutrinária oficial é a Confissão de Fé de Westminster, redigida por determinação do parlamento inglês. Os trabalhos tomaram cinco anos e meio, participando ministros ou teólogos (alguns das universidades de Oxford e Cambridge e delegados da Escócia). ${ }^{8}$

João Calvino defendia ideias e princípios morais rígidos, o trabalho e a poupança como duas virtudes a serem valorizadas pelo verdadeiro cristão, valorizando também o trabalho e a contenção dos lucros que atraíram vários representantes da burguesia europeia. O calvinismo serviu de ponto de partida e inspiração para que o sistema capitalista se desenvolvesse, com ideias como a de trabalho árduo, acúmulo de capitais, que impulsionaram o desenvolvimento dos negócios e empreendimentos, criando novas nações ricas. ${ }^{9}$

AposiçãodeCalvino, portanto, consistiana crença de diversas denominações tradicionais, como os presbiterianos, anglicanos e alguns batistas, por exemplo. Ele foi um dos expoentes da reforma protestante que enfatizou a doutrina da predestinação, afirmando que o ser humano só pode usufruir da salvação eterna dispensada pelos méritos de Cristo se tiver sido predestinado para tal. "... e creram todos quantos haviam sido destinados para a vida eterna". ${ }^{10}$

Calvino ensinava que essa predestinação se baseava exclusivamente na livre graça de Deus, independentemente de qualquer ato ou fé previsto do pecador que viesse a torná-lo agradável a Deus. "Nele, digo, em quem também fomos feitos herança, havendo sido predestinados, conforme o propósito daquele que faz todas as coisas, segundo o conselho da sua vontade". ${ }^{11}$

De acordo com Delfstra, Calvino desenvolveu a teoria calvinista,

\footnotetext{
${ }^{8}$ FEINBERG, John; et al. Predestinação e livre-arbítrio. 3.ed. São Paulo: Mundo Cristão, 2000, p. 14.

${ }^{9}$ GEORGE, Timothy. Teologia dos Reformadores. São Paulo: Vida Nova, 1994, p. 10.

${ }^{10}$ Atos 13.48 .

${ }^{11}$ Efésios 1.11.
} 
representada pelo acrônimo TULIP conhecido como os Cinco Pontos do Calvinismo, derivados do Sínodo de Dort, um sínodo local convocado em 1618-1619 na Holanda:

- Total Depravity - Depravação Total (o pecado atingiu o homem tão profundamente que o inabilitou de qualquer capacidade de dar resposta positiva aos apelos do Evangelho);

- Unconditional Election - Eleição Incondicional (Deus, na sua graça infinita, elegeu a Igreja para a salvação independente de qualquer ato previsto);

- Limited Atonement - Expiação Limitada (Cristo morreu na cruz do Calvário somente pelos eleitos, ou seja, somente aqueles que são predestinados para a salvação é que serão eficazmente salvos);

- Irresistible Grace - Graça Irresistível (Todos os eleitos serão, no devido tempo, atraídos pelo Espirito Santo a Cristo para alcançar a salvação. Nenhum dos escolhidos de Deus deixará de receber a salvação através de Cristo);

- Perseverance of the Saints - Perseverança dos Santos (todos os eleitos perseverarão na fé até o final de sua jornada aqui neste mundo, jamais cairão da graça de Deus que os sustenta). ${ }^{12}$

Segundo Calvino, quando uma pessoa se arrepende é inteiramente pelo poder atrativo do Espírito Santo. Para ele, a predestinação é o "decreto" de Deus através do qual Ele decidiu quem seria ou não salvo. ${ }^{13}$

Sempre afirmou que se fosse verdade que Jesus veio para morrer por todas as pessoas, então a humanidade estaria diante de um Deus impotente, que foi capaz de criar todas as coisas, mas incapaz de salvar o homem. Ele não salva a todos, porque Ele não veio para todos, mas só para os seus. Há pessoas a quem Ele não amou porque não eram os seus. ${ }^{14}$

Os pastores que seguem as teorias de João Calvino ensinam que Cristo veio, não para morrer por todos, mas para aqueles que fazem parte da Sua Igreja. Estes serão salvos porque foram predestinados para a salvação, a qual pertence inteiramente a Deus. Isso significa que o homem nada tem a ver com

\footnotetext{
${ }^{12}$ DELFSTRA, Gerrit. A doutrina da predestinação de Calvino até Armínio. Monografia apresentada para o Mestrado em Teologia, 1984, p. 21.

${ }^{13}$ HANKO, Herman. João Calvino: o reformador suíço. Disponível em: http://monergismo. com/herman-hanko/joao-calvino-o-reformador-suico/. Acesso 19 Dez. 2017. p. 2.

${ }^{14} \mathrm{HANKO}, 2017$, p. 3 .
} 
a sua salvação e Deus a concede para quem Ele quer..$^{15}$

A doutrina de João Calvino explica que os "filhos de Deus" são os predestinados para a salvação, enquanto que os "filhos do diabo" são destinados à perdição. Segundo os Calvinistas, Caim teria nascido destinado à perdição e por isso matou Abel, seu irmão. Dizem ainda que de Caim descendem todos os filhos da perdição: Faraó, Judas, Herodes, etc. Segundo essa teoria existe atualmente duas sementes no mundo: a semente do bem (os predestinados para a salvação) e a semente do mal (os destinados à perdição). ${ }^{16}$

No entender de Calvino, a doutrina central do cristianismo é a da majestade de Deus. E a miséria humana precisa se defrontar com a majestade divina. O fim último de toda a realidade é a autoglorificação de Deus. Tanto a bemaventurança dos redimidos, quanto o inferno para os condenados têm em vista um só objetivo: a glória e a majestade de Deus, que criou o bem como o mal, a fim de evidenciar sua honra divina. Calvino desenvolveu a doutrina da predestinação em sua obra Institutio Religionis Christianae, livro III, Capítulos XXI a XXIV. Calvino desenvolveu a doutrina da predestinação no final do terceiro livro, antes de abordar a cristologia. Neste contexto, em que é abordada a vida cristã, o Reformador analisou a predestinação como uma doutrina prática, que serve de base para a cristologia. ${ }^{17}$

Se o calvinismo fosse a interpretação correta da Bíblia, o cristianismo seria, portanto, irrelevante. É difícil ver a utilidade (ou até a eficácia) do evangelismo, dada a veracidade do calvinismo. Se o calvinismo fosse correto, é difícil entender até mesmo o motivo da existência, relevância e função dos apóstolos, da igreja e do cristianismo em si. ${ }^{18}$

Se uma pessoa é salva incondicionalmente, então não há necessidade de pregar, deanunciaroevangelho, delera Bíblia.Se Deus nãoestivesseinteressado na vida humana, elegendo e condenando pessoas independentemente das próprias pessoas, por que se daria ao trabalho de se revelar e ordernar que a palavra seja pregada a toda criatura viva? ${ }^{19}$

Quando João diz: “está consumado”, ele quer dizer quer tudo está pago e isto representa a salvação para o cristão. Tudo foi comprado no calvário.

\footnotetext{
${ }^{15}$ GEORGE, 1994, p. 21.

${ }^{16}$ HANKO, 2017, p. 3.

${ }^{17}$ DUDUS, Gérson. Teologia dos Reformadores. São Paulo: Vida Nova, 1994, p. 39.

${ }^{18}$ CALVINO, João. As Institutas. São Paulo: Cultura Cristã, 2006, p. 44.

${ }^{19}$ CALVINO, 2006, p. 45.
} 
Abrange cada fase de nossas necessidades e dura de eternidade a eternidade. Inclui a libertação do pecado no presente e a apresentação contra as invasões do pecado no futuro. ${ }^{20}$

Ora, àquele que é poderoso para vos guardar de tropeçar, e apresentarvos irrepreensíveis, com alegria, perante a sua glória. Ao único Deus sábio, Salvador nosso, seja glória e majestade, domínio e poder, agora, e para todo o sempre. ${ }^{21}$

Porque a graça de Deus se manifestou salvadora a todos os homens. Ela nos ensina a renunciar à impiedade e às paixões mundanas e a viver de maneira sensata, justa e piedosa nesta era presente, enquanto aguardamos a bendita esperança: a gloriosa manifestação de nosso grande Deus e Salvador, Jesus Cristo. $^{22}$

Ao contrário do que muitos pensam, não foi João Calvino quem escreveu “Os Cinco Pontos do Calvinismo”. No entanto, a pergunta que se faz é: se não foi Calvino, quem foi então? Estes cinco pontos foram formulados pelo Sínodo de Dort. Portanto, é incorreto afirmar que João Calvino é o autor destes cinco pontos, porque na verdade, a afirmação correta é que estes "pontos” foram fundamentados tão somente nas doutrinas ensinadas por ele. Aliás, este sistema doutrinário, se assim podemos chamá-lo, foi elaborado somente 54 anos após a morte do grande reformador que viveu de 1509 a $1564 .{ }^{23}$

Entre os principais discípulos de Calvino, estão Teodoro de Beza (1519 1605 - teólogo protestante francês que desempenhou um papel importante no início da Reforma Protestante), Zacharias Ursinus (1534 - 1583 - teólogo, pregador e reformador alemão), Ashbel Green Simonton (1833 - 1867 fundador da Igreja Presbiteriana do Brasil), e José Manoel da Conceição (1822 - 1873 - primeiro pastor evangélico do Brasil). ${ }^{24}$

\section{ARMINIIO: SEU NASCIMENTO, SUA HISTÓRIA E SEUS PRINCIPAIS}

Delfstra conta que Jacó Armínio foi um teólogo holandês (1560 - 1609), nascido em Oudewater, Utrecht. Muito jovem tornou-se órfão de pai (Hermann

\footnotetext{
${ }^{20}$ João 19.30.

${ }^{21}$ Judas 24.25.

${ }^{22}$ Tito 2.11-13.

${ }^{23}$ CALVINO, 2006, p. 59.

${ }^{24}$ HANKO, 2017, p. 4.
} 
Jakobs), que deixou uma viúva com três filhos pequenos para criar. A sua mãe (Angélica), irmãos e parentes morreram durante o massacre espanhol em Oudewater em 1575. O pastor Theodorus Aemilius adotou Armínio e o enviou para ser instruído em Utrecht, após a sua morte, coube ao professor Rudolph Snellius trazê-lo a Marburgo e o qualificar para estudar teologia na recémfundada Universidade de Leiden (1576-1582). ${ }^{25}$

A sua formação teológica em Leiden, entre 1576 a 1582, incluiu os professores Lambertus Danaeus, Johannes Drusius, Guillaume Feuguereius e Johann Kolmann. Kolmann ensinava que o hiper-calvinismo transformava Deus em um tirano e homicida, sob a sua influência Armínio começou a elaborar uma teologia que competiria com teologia reformada dominante de Calvino.

Em 1582, Armínio tornou-se aluno de Theodoro de Beza em Genebra. O uso do método filosófico ramista o forçou a mudar-se para Basileia (15821584), onde assistiu às aulas de J. J. Grynaeus. De volta a Genebra, Armínio fez amizade com Johannes Uyttenbogaert, que viria a ser o seu principal aliado nas futuras discussões teológicas.

Em 1588, ele foi chamado para ser pastor em Amsterdã, a partir de então, Armínio ganhou reputação como um promissor teólogo, bem educado em Marburgo, Leiden, Genebra, Basileia, Pádua e recomendado por Beza. Em 16 de setembro de 1590 ele se casou com Lijsbet Reael, uma aristocrata que lhe garantiu circular entre os comerciantes e líderes mais influentes da cidade. Em 1591, no entanto, ele se envolveu em uma disputa com um imigrante flamengo chamado Petrus Plancius (1552-1622), em que foi necessário a intervenção do consistório, pelos burgomestres de Amsterdã, para manter a paz e abafar as divisões na população. ${ }^{26}$

A morte quase simultânea em 1602 de dois professores da Universidade de Leinden abriu espaço para que Armínio fosse chamado para ensinar teologia. Sua admissão trouxe um novo período de debates teológicos e teve apoio político de Johannes Uyttenbogaert e Johan van Oldenbarvenelt. Armínio faleceu em outubro de 1609, vítima de tuberculose.

Jacob Arminius, um teólogo holandês, discordando de Calvino, passou a ensinar que o pecado não inabilitou o homem totalmente e sim que ele ainda

\footnotetext{
${ }^{25}$ DELFSTRA, 1984, p. 39.
}

${ }^{26}$ DELFSTRA, 1984, p. 41. 
conservava a faculdade de por si mesmo, independente da ação divina, de dar resposta ao evangelho de Cristo. Arminius queria dizer que o homem colaborava com a sua salvação, pois ele tinha o livre-arbítrio de aceitar ou de rejeitar a obra redentora de Cristo. Afirmava, ainda, que a salvação uma vez recebida poderia ser perdida se o indivíduo não perseverasse na fé. ${ }^{27}$

Armínio acreditava que uma vez que Deus quer que todos os homens sejam salvos, ele envia seu Santo Espírito para atrair todos os homens a Cristo. Contudo, desde que o homem goza de vontade livre absoluta, ele pode resistir à vontade de Deus em relação a sua própria vida. Em outras palavras, a ordem arminiana sustenta que, primeiro, o homem exerce sua própria vontade e só depois nasce de novo. Para Armínio, o homem não pode continuar na salvação, a menos que continue a querer ser salvo. ${ }^{28}$

Armínio ensinava que a vontade de Deus é que “todos” os homens sejam salvos, porque Cristo morreu por todos os homens, baseado principalmente no seguinte versículo: "Porque Deus amou o mundo de tal maneira que deu o seu Filho Unigênito, para que todo o que nele crer não pereça, mas tenha a vida eterna". ${ }^{29}$

Também ensinava que o fator decisivo para a determinação de quem será salvo é a decisão humana. A ênfase no livre arbítrio tem levado a escola católica e arminiana a negar as principais doutrinas soteriológicas, como por exemplo, a justificação pela graça mediante a fé, ainda que os arminianos façam isso de forma inconsciente. ${ }^{30}$

As raízes do arminianismo, dizem alguns teólogos, estão em Pelágio, que pregava um tipo de autossalvação, negava que o homem é depravado e negava que Deus tem algum plano. Armínio dedicou-se com afinco ao estudo das doutrinas calvinistas, a fim de combater mais eficazmente as ideias pelagianas. Entretanto, o calvinista Armínio, surpreendentemente, chegou à conclusão de que o calvinismo estava errado e passou a defender a posição que vinha atacando. Simon Episcopius (1583-1643) é quem sistematizou o arminianismo. ${ }^{31}$

\footnotetext{
${ }^{27}$ DELFSTRA, 1984, p. 41-42.

${ }^{28}$ FEINBERG, 2000, p. 22.

${ }^{29}$ João 3.16.

${ }^{30}$ OLSON, Roger. Teologia Arminiana: mitos e realidades. São Paulo: Reflexão, 1992, p. 86.

${ }^{31}$ FEINBERG, 2000, p. 24.
} 
Feinberg conta que, em 1610, após a morte de Arminius, quarenta e quatro pregadores da igreja reformada da Holanda escreveram cinco artigos contra a radicalidade da doutrina da predestinação: Deus destinou para a bemaventurança aqueles que creem; Cristo morreu por todos; A fé salvadora não advém da livre vontade humana, mas de Deus; Esta graça não é irresistível; e Fica aberta a questão se os cristãos podem novamente decair. Estes arminianos foram chamados de Remonstrantes. O armianismo pode ser representado pelo acrônimo FACTS:

- $\quad$ Freed by Grace (to Believe) - Livre pela graça (sustenta que o homem é dotado de vontade livre e que a graça é resistível);

- $\quad$ Atonement for All - Expiação para Todos (a morte de Cristo oferece a Deus base para salvar a todos os homens, contudo, cada homem deve exercer sua livre vontade para aceitar a Cristo);

- Conditional Election - Eleição Condicional (a eleição baseada no préconhecimento de Deus em relação àquele que deve crer);

- Total Depravity - Depravação Total (O homem é tão depravado que a graça divina é necessária para a fé ou para qualquer boa obra);

- Security in Christ - Segurança em Cristo (Cristo morreu por todos e cada um dos homens, embora só os crentes sejam salvos). ${ }^{32}$

Em 1611, surgiram os "Contrarremonstrantes", que eram seguidores de Gomarus, e a questão extrapolou o âmbito eclesiástico e foi decidida na esfera política. ${ }^{33}$

Em 1618, os remonstrantes (seguidores de Armínio), liderados por Simão Episcópio, entregaram um escrito ao Sínodo de Dort. Os discípulos de Armínio apresentaram uma representação (que ficou conhecida como "Remonstrância”) ao Parlamento Holandês, para que os cinco pontos do arminianismo fossem declarados como o novo padrão doutrinário daquele país. Para decidir a questão, foi convocado o Sínodo de Dort (reunião dos principais teólogos do país que contou com a participação de oitenta e quatro teólogos e treze delegados seculares). Dort vem de Dordrecht, cidade holandesa local da reunião. O Sínodo de Dort ficou reunido por cerca de sete meses, de 13 de novembro de 1618 a maio de $1619 .^{34}$

\footnotetext{
32 FEINBERG, 2000, p. 35.

${ }^{33}$ OLSON, 1992, p. 88.

${ }^{34}$ CULTURA CRISTÃ. Os Cânones de Dort. 3.ed. São Paulo: Cultura Cristã, 2016, p. 63.
} 
Foram cento e cinquenta e quatro reuniões, nas quais os Cinco Pontos do Arminianismo foram examinados e comparados com as Escrituras Sagradas. Ao final, os teólogos concluíram que os Cinco Pontos do Arminianismo são contrários ao ensino da Bíblia. Então, o Sínodo de Dort formulou os cinco pontos do calvinismo: total depravação do homem, eleição incondicional, expiação limitada, graça irresistível e perseverança dos santos, concluindo que: Deus escolhe a partir de um decreto eterno, Cristo morreu somente pelos eleitos, a graça é irresistível e os santos perseverarão na fé. ${ }^{35}$

\section{DIFERENCAS DOUTRINÁRIAS: CALVINISMO X ARMINIANISMO}

A doutrina calvinista e a doutrina arminiana apresentam diferenças significativas. O Calvinismo defende a "eleição incondicional", enquanto que o Arminianismo defende a "eleição condicional". A "eleição incondicional" afirma que Deus elege pessoas para a salvação baseado inteiramente em Sua vontade e não em nada inerentemente digno na pessoa. A “eleição condicional” afirma que Deus elege pessoas para a salvação baseado em sua pré-ciência de quem crerá em Cristo para a salvação. ${ }^{36}$

O Calvinismo defende a "graça irresistível", enquanto que o Arminianismo diz que um indivíduo pode resistir a graça de Deus. A "graça irresistível” defende que quando Deus chama alguém para a salvação, esta pessoa inevitavelmente virá para a salvação. A "graça resistível” afirma que Deus chama a todos para a salvação, mas muitas pessoas resistem e rejeitam este chamado. ${ }^{37}$

O Calvinismo defende a "expiação limitada", e o Arminianismo defende a “expiação ilimitada”. Este, dos cinco pontos, é o mais polêmico. A “expiação limitada” é a crença de que Jesus morreu apenas pelos eleitos. A "expiação ilimitada” é a crença de que Jesus morreu por todos, mas que Sua morte não tem efeito enquanto a pessoa não crer. ${ }^{38}$

O Calvinismo defende a "perseverança dos santos", enquanto que o Arminianismo defende a "salvação condicional”. A "perseverança dos santos" se refere ao conceito de que a pessoa que é eleita por Deus irá perseverar em fé e nunca negará a Cristo ou se desviar Dele. A “salvação condicional” é a visão

\footnotetext{
${ }^{35}$ HORTON, Michael. Calvino e a vida cristã. São Paulo: Cultura Cristã, 2017, p. 101.

${ }^{36}$ HORTON, 2017, p. 103.

${ }^{37}$ HORTON, 2017, p. 104.

${ }^{38}$ BERKHOF, 1992, p. 19.
} 
de que um crente em Cristo pode, por seu livre arbítrio, se desviar de Cristo e, assim, perder a salvação. Observação: Muitos arminianos negam a "salvação condicional" e, em vez disso, adotam a "segurança eterna".

Arminius rejeitou o supralapsarismo, pois entendia que esta ideia não está de acordo com o cerne do Evangelho. E a ideia também não está em harmonia com as confissões reformadas. Declarou também que a doutrina do supralapsarismo é uma desonra a Cristo "porque o exclui completamente do decreto que predetermina o fim". Arminius não podia admitir que "os homens foram predestinados a serem salvos, antes que Cristo fosse predeterminado a salvá-los”. E enfatiza que o fundamento da eleição é Cristo. ${ }^{39}$

Calvinismo é o termo utilizado por pessoas que identificam João Calvino como o maior organizador e produtor de verdades bíblicas no período da reforma protestante. Calvinismo é a teologia que entende e enfatiza que Deus é o único responsável pela salvação do homem, ou seja, Deus faz valer sua soberania e poder para que todo aquele que foi previamente escolhido e, ainda mais, que foi criado para ser salvo, seja salvo. ${ }^{40}$

Neste ponto de vista o sacrifício salvífico de Jesus Cristo na cruz para redimir o homem do pecado e torná-lo reconciliável com seu criador se torna limitado, tendo em vista que Jesus não morreu por todos, mas somente para os que já foram criados para serem salvos, evidenciando os que foram criados para serem lançados ao inferno. Os arminianos divergem dos calvinistas neste ponto, pois acreditam que o homem pode contribuir ou não para a salvação, tendo o poder de escolha, entre o aceitar e o recusar, entendendo assim que a graça pode ser resistível e não irresistível como acreditam os calvinistas. Este grupo entende que quando a Bíblia em diversas passagens trata dos predestinados à salvação, refere-se ao atributo divino de onisciência, e não vê as coisas como passado presente e futuro. Sendo assim, quando cria um indivíduo já consegue ver se este em algum momento de sua vida se voltará para seu criador e aceitará o sacrifício de Jesus que morreu para salvar todo aquele que crer. ${ }^{41}$

Delfstra (1984) $)^{42}$ estabelece comparações entre os pontos preponderantes

\footnotetext{
${ }^{39}$ BERKHOF, 1992, p. 20.

${ }^{40}$ HORTON, 2017, p. 104.

${ }^{41}$ OLSON, 1992, p. 91.

${ }^{42}$ DELFSTRA, 1984, p. 41-44.
} 
de ambas as doutrinas:

\subsection{COMPARAÇ̃̃O DO PONTO 1}

O arminianismo diz que a vontade do homem é 'livre' para escolher, ou a Palavra de Deus, ou a palavra de Satanás. A salvação, portanto, depende da obra de sua fé.

O calvinismo responde que o homem não regenerado é absolutamente escravo de Satanás e, por isso, é totalmente incapaz de exercer sua própria vontade livremente (para salvar-se), dependendo, portanto, da obra de Deus, que deve vivificar o homem, antes que este possa crer em Cristo.

\subsection{COMPARAÇ̃̃O DO PONTO 2}

Arminius sustentava que a 'eleição' é condicional, enquanto os reformadores sustentavam que ela é incondicional. Os arminianos acreditam que Deus elegeu àqueles a quem 'pré-conheceu', sabendo que aceitariam a salvação, de modo que o pré-conhecimento de Deus estava baseado na condição estabelecida pelo homem.

Os calvinistas sustentam que o pré-conhecimento de Deus está baseado no propósito ou no plano de Deus, de modo que a eleição não está baseada em alguma condição imaginária inventada pelo homem, mas resulta da livre vontade do Criador à parte de qualquer obra de fé do homem espiritualmente morto.

Dever-se-á notar ainda que a segunda posição de cada um destes partidos (arminianos e calvinistas) é expressão natural de suas respectivas doutrinas a respeito do homem. Se o homem tem "vontade livre" e não é escravo nem de Satanás nem do pecado, então ele é capaz de criar a condição pela qual Deus pode elegê-lo e salvá-lo. Contudo, se o homem não tem vontade livre sua única esperança é que Deus o tenha elegido para a salvação.

A Eleição é doutrina fundamental no pensamento cristão sobre a salvação. Nada se pode entender das obras de Deus se não se toma por princípio que ele quis cegar a uns e esclarecer os outros. Diante desse fato ninguém dentro da ortodoxia teológica desacredita nessa verdade. No entanto, não se tem um conceito sólido sobre o assunto, pois dentro da ortodoxia teológica encontramse, basicamente, duas formas de Eleição: a Eleição Incondicional (Calvinismo) 
e a Eleição Prevista (Arminianismo). ${ }^{43}$

Porém, ainda é possível observar fora da ortodoxia teológica versões sobre a salvação, pois há quem pense que Deus escolheu todos os seres humanos, de todos os lugares do mundo e de todas suas eras para a salvação (Universalismo). Assim, é necessário compreender tais possibilidades para que a verdade bíblica seja ressaltada. ${ }^{44}$

“A salvação tem o propósito de trazer glória eternamente a Deus, e, essa glória na salvação, é por Jesus Cristo para todo o sempre. Ao único Deus sábio seja dada glória para todo o sempre, por meio de Jesus Cristo. Amém”. 45

"Porque Deus, que disse que das trevas resplandecesse a luz, é quem resplandeceu em nossos corações, para iluminação do conhecimento da glória de Deus, na face de Jesus Cristo". ${ }^{46}$

"E o Deus de toda a graça, que em Cristo Jesus nos chamou à sua eterna glória, depois de havemos padecido um pouco, ele mesmo vos aperfeiçoe, confirme, fortifique e estabeleça". ${ }^{47}$

O livre arbítrio do homem é axioma cristão. Toda moral, sob a Lei ou sob o Evangelho, o responsabiliza e o considera capaz de considerar motivos, pesar alternativas, calcular necessários para os atingir..$^{48}$

O significado universal de Jesus como o Cristo pode também ser expresso no termo "salvação". Ele mesmo é chamado Salvador, Mediador ou Redentor. O termo salvação tem tantas conotações quantas são as negatividades que necessitam de salvação. Mas pode-se distinguir salvação com relação à negatividade última e com relação àquilo que conduz à negatividade última. Negatividade última é chamada de condenação ou morte eterna, a exclusão da unidade universal do Reino de Deus, a exclusão da vida eterna. ${ }^{49}$

Para os calvinistas, a predestinação é decreto de Deus, no qual o fato de que alguns que são chamados pelo evangelho obedecerem ao chamado e serem convertidos não deve ser atribuído ao exercício próprio do livrearbítrio, mas deve ser totalmente atribuído a Deus que, assim como escolheu os seus próprios desde a eternidade em Cristo, chama-os eficazmente no

\footnotetext{
${ }^{43}$ GEORGE, 1994, p. 65.

${ }^{44}$ GEORGE, 1994, p. 67.

${ }^{45}$ Romanos 16.27.

${ }^{46}$ II Coríntios 4.6.

${ }^{47}$ I Pedro 5.10.

${ }^{48}$ TILLICH, Paul. Teologia Sistemática. São Paulo: Paulinas, 1984, p. 70.

${ }^{49}$ TILLICH, 1984, p. 71.
} 
tempo apropriado, confere-lhes a fé e o arrependimento, resgata-os do poder da escuridão e transporta-os para o reino do seu próprio Filho; para que possam proclamar os louvores daquele que os fez sair da escuridão para a sua luz maravilhosa e possam gloriar-se não em si mesmos, mas no Senhor, de acordo com o testemunho dos apóstolos em vários lugares. ${ }^{50}$

Algumas passagens bíblicas que mostram, segundo o Calvinismo, que Deus tem um povo eleito:

"Eis que do Senhor teu Deus são o céu e o céu dos céus, a terra e tudo o que nela há. Entretanto o Senhor se afeiçoou a teus pais para os amar; e escolheu a sua descendência depois deles, isto é, a vós, dentre todos os povos, como hoje se vê". ${ }^{1}$

"Bem-aventurada é a nação cujo Deus é o Senhor, o povo que ele escolheu para sua herança". ${ }^{2}$

"Todas as coisas me foram entregues por meu Pai; e ninguém conhece plenamente o Filho, senão o Pai; e ninguém conhece plenamente o Pai, senão o Filho, e aquele a quem o Filho o quiser revelar". ${ }^{53}$

"Porque muitos são chamados, mas poucos escolhidos". ${ }^{54}$ " $E$ se aqueles dias não fossem abreviados, ninguém se salvaria; mas por causa dos escolhidos serão abreviados aqueles dias" (ALMEIDA, BÍBLIA SAGRADA, 1999, Mateus, 24: 22).

"E não fará Deus justiça aos seus escolhidos, que dia e noite clamam a ele, já que é longânimo para com eles?". ${ }^{55}$ "E sabemos que todas as coisas concorrem para o bem daqueles que amam a Deus, daqueles que são chamados segundo o seu propósito". ${ }^{56}$

"Porque os que dantes conheceu, também os predestinou para serem conformes à imagem de seu Filho, a fim de que ele seja o primogênito entre muitos irmãos; e aos que predestinou, a estes também chamou; e aos que chamou, a estes também justificou; e aos que justificou, a estes também glorificou'. ${ }^{57}$

"Quem intentará acusação contra os escolhidos de Deus?

\footnotetext{
${ }^{50}$ TILLICH, 1984, p. 72.

${ }^{51}$ Deuteronômio 10.14-15.

${ }^{52}$ Salmos 33.12.

${ }^{53}$ Mateus 11.27.

${ }^{54}$ Mateus 22.14.

${ }^{55}$ Lucas 18.7.

${ }^{56}$ Romanos 8.28.

${ }^{57}$ Romanos 8.29-30.
} 
É Deus quem os justifica". ${ }^{8}$

"Revesti-vos, pois, como eleitos de Deus, santos e amados, de coração compassivo, de benignidade, humildade, mansidão, longanimidade". 59

"Porque Deus não nos destinou para a ira, mas para alcançarmos a salvação por nosso Senhor Jesus Cristo". ${ }^{60}$ "Mas vós sois a geração eleita, o sacerdócio real, a nação santa, o povo adquirido, para que anuncieis as grandezas daquele que vos chamou das trevas para a sua maravilhosa luz". ${ }^{61}$

"Estes combaterão contra o Cordeiro, e o Cordeiro os vencerá, porque é o Senhor dos senhores e o Rei dos reis; vencerão também os que estão com ele, os chamados, e eleitos, e fiéis". ${ }^{62}$

Deus fez a escolha: "Mas nós devemos sempre dar graças a Deus por vós, irmãos, amados do Senhor, porque Deus vos escolheu desde o princípio para a santificação do espírito e a fé na verdade". ${ }^{63}$ Segundo Tillich, a eleição não é a salvação, mas é para a salvação. Assim como o presidente eleito não se torna o presidente de fato até o dia da sua posse (instalação), assim aqueles que são eleitos para a salvação não são salvos até que sejam regenerados pelo Espírito e justificados pela fé em Cristo. ${ }^{64}$

Paulo mostra que os homens foram eleitos "em Cristo" antes que o mundo existisse. ${ }^{65}$ Tillich (1984) afirma que a eleição foi baseada na misericórdia soberana e especial de Deus. Não foi a vontade do homem, mas a vontade de Deus que determinou que pecadores seriam salvos da misericórdia e ser salvos. As Escrituras não apenas ensinam que Deus predestinou certos indivíduos para a vida eterna, mas que todos os eventos, grandes ou pequenos, acontecem como o resultado do eterno decreto de Deus. O Senhor Deus reina sobre os céus e a terra com absoluto controle. Nada acontece fora do Seu eterno propósito. ${ }^{66}$

A exposição agostiniana da graça, por exemplo, desemboca na doutrina

\footnotetext{
${ }^{58}$ Romanos 8.33.

${ }^{59}$ Colossenses 3.12.

${ }^{60}$ Tessalonicenses 5.9.

${ }^{61}$ I Pedro 2.9.

${ }^{62}$ Apocalipse 17.14 .

${ }^{63}$ II Tessalonicenses 2.13 .

${ }^{64}$ TILLICH, 1984, p. 67.

${ }^{65}$ Efésios 1.4.

${ }^{66}$ TILLICH, 1984, p. 69.
} 
da eleição. Agostinho cria que aquilo que Deus faz na história do homem pecador que é regenerado, é na verdade algo que o Senhor já havia decretado na eternidade. Sendo assim, a eleição só pode ser incondicional, pois se Deus escolhesse o homem tendo por base o conhecimento que tais homens viessem a crer em Cristo futuramente, Deus estaria apenas trabalhando em cima do que o homem, através de sua livre ação, determinasse.

Já, acerca dos não eleitos, Agostinho considerava o decreto de Deus como mera omissão. A reprovação é diferente da eleição no fato que aquela não é seguida por nenhuma eficiência divina para garantir o resultado intentado. Calvino, ao ensinar a Doutrina da Eleição, nunca foi além do que as Escrituras afirmam sobre tal assunto. A predestinação nem pode ser considerada a doutrina central nos escritos de Calvino, embora ela seja de suma importância em sua teologia. O Reformador de Genebra a ensinou com zelo e reverência os decretos inescrutáveis do Senhor. ${ }^{67}$

\subsection{COMPARAC̄̃̃O DO PONTO 3}

Os arminianos insistem em que a expiação (e, por esta palavra, eles significam 'redenção') é universal. Os calvinistas, por sua vez, insistem em que a Redenção é parcial, isto é, a Expiação Limitada é feita por Cristo na cruz.

Ainda segundo o arminianismo, Cristo morreu para salvar não um em particular, porém somente àqueles que exercem sua vontade livre e aceitam o oferecimento de vida eterna. Daí a morte de Cristo foi um fracasso parcial, uma vez que os que têm volição negativa, isto é, os que não a querem aceitar, irão para o inferno.

Já para o calvinismo, Cristo morreu para salvar pessoas determinadas, que lhe foram dadas pelo Pai desde toda a eternidade. Sua morte, portanto, foi cem por cento bem-sucedida, porque todos aqueles pelos quais ele não morreu receberão a "justiça" de Deus, quando forem lançados no inferno.

\subsection{COMPARAÇ̃̃O DO PONTO 4}

Os arminianos afirmam que, ainda que o Espírito Santo procure levar todos os homens a Cristo (uma vez que Deus ama a toda a humanidade e deseja salvar a todos os homens), ainda assim, como a vontade de Deus está

\footnotetext{
$\overline{{ }^{67} \text { BERKHOF, 1992, p. }} 81$.
} 
amarrada à vontade do homem, o Espírito de Deus pode ser resistido pelo homem, se o homem assim o quiser. Desde que só o homem pode determinar se quer ou não ser salvo, é evidente que Deus, pelo menos, 'permite' ao homem obstruir sua santa vontade. Assim, Deus se mostra impotente em face da vontade do homem, de modo que a criatura pode ser como Deus, exatamente como Satanás prometeu a Eva, no jardim do Éden.

Calvinistas respondem que a graça de Deus não pode ser obstruída, visto que sua graça é irresistível. Os calvinistas não querem significar com isso que Deus esmaga a vontade obstinada do homem como um gigantesco rolo compressor! A graça irresistível não está baseada na onipotência de Deus, ainda que poderia ser assim, se Deus o quisesse, mas está baseada mais no dom da vida, conhecido como regeneração.

Desde que todos os espíritos mortos (alienados de Deus) são levados a Satanás, o deus dos mortos, e todos os espíritos vivos (regenerados) são guiados irresistivelmente para Deus (o Deus dos vivos), nosso Senhor, simplesmente, dá a seus escolhidos o Espírito de Vida. No momento em que Deus age nos eleitos, a polaridade espiritual deles é mudada: Antes estavam mortos em delitos e pecados, e orientados para Satanás; agora são vivificados em Cristo e orientados para Deus.

É neste ponto que aparece outra grande diferença entre a teologia arminiana e a teologia calvinista. Para os calvinistas a ordem é: primeiro o dom da vida, por parte de Deus; e, depois, a fé salvadora, por parte do homem.

\subsection{COMPARAÇ̃̃O DO PONTO 5}

Os arminianos concluem, muito logicamente, que o homem, sendo salvo por um ato de sua própria vontade livremente exercida, aceitando a Cristo por sua própria decisão, pode também perder-se depois de ter sido salvo, se resolver mudar de atitude para com Cristo, rejeitando-o.

Alguns arminianos acrescentariam que o homem pode perder, subsequentemente, sua salvação, cometendo algum pecado, uma vez que a teologia arminiana é uma "teologia de obras", pelo menos no sentido e na extensão em que o homem precisa exercer sua própria vontade para ser salvo.

Esta possibilidade de perder-se, depois de ter sido salvo, é chamada de "queda ou perda da graça”, pelos seguidores de Arminius. Ainda, se depois de ter sido salva, a pessoa pode perder-se, ela pode tornar-se livremente a Cristo 
outra vez e, arrependendo-se de seus pecados, “pode ser salva de novo”. Tudo depende de sua contínua volição positiva até à morte.

Os calvinistas sustentam muito simplesmente que a salvação, desde que é obra realizada inteiramente pelo Senhor (e que o homem nada tem a fazer antes, absolutamente, "para ser salvo"), é óbvio que o "permanecer salvo" é, também, obra de Deus, à parte de qualquer bem ou mal que o eleito possa praticar. Os eleitos 'perseverarão' pela simples razão de que Deus prometeu completar, em nós, a obra que ele começou. Por isso, os cinco pontos de TULIP incluem a Perseverança dos Santos.

\section{CONSIDERACÕ̃ES FINAIS}

Os cinco pontos do arminianismo são depravação total, expiação para todos, livre pela graça (para crer), eleição condicional e segurança em Cristo, os quais foram condenados pelo Sínodo de Dort e, a partir de então, foram formulados os cinco pontos do calvinismo: total depravação do homem, eleição incondicional, expiação limitada, graça irresistível e perseverança dos santos.

Sob o ponto de vista arminiano, a salvação é um resultado da combinação dos esforços de Deus (que toma a iniciativa) e do homem (que deverá corresponder à iniciativa divina), mas a resposta do homem é o fato determinante, porque Deus providenciou a salvação para todos, porém, essa provisão se torna efetiva somente para aqueles que, por sua própria vontade, escolherem cooperar com Deus e aceitarem sua oferta de graça. Assim sendo, o homem, e não Deus, resolve quem serão os recipientes da salvação.

Considerando o ponto de vista calvinista, a salvação é realizada pelo poder do Deus, no qual o Pai escolheu um povo, o Filho morreu por esse povo e o Espírito Santo torna a morte de Cristo eficaz, ao trazer os eleitos à fé e ao arrependimento, levando-os a obedecerem voluntariamente ao evangelho. Logo, Deus, e não o homem, determina quem serão os agraciados pelo dom da salvação. Assim como o calvinismo, o arminianismo também formulou doutrinas importantes que contribuíram para a história da igreja, no período pós reforma, ultrapassando os limites de tempo, eclodindo ainda nos dias atuais.

O desenvolvimento deste artigo permite ressaltar que tanto o Arminianismo quanto o Calvinismo enfatizam a responsabilidade humana e sua necessidade 
de expressar uma vida santa e reta como evidência de sua eleição. Os mesmos textos bíblicos que dão subsídios teológicos-reflexivos para uma perspectiva o fazem para a outra. Dessa forma, é possível encontrar calvinistas e arminianos defendendo, a partir do mesmo texto, suas perspectivas, mudando apenas a abordagem. Tomando como exemplo o texto de João 3: 16, vê-se a doutrina arminiana defendendo a expiação universal, afirmando que Cristo morreu por todos. Por outro lado, a partir do mesmo texto, a doutrina calvinista afirma que o mundo aponta para os eleitos.

Por fim, conclui-se que é dever do cristão examinar as Escrituras e buscar aquilo o que elas trazem. Nem sempre as respostas podem coadunar-se a um sistema teológico previamente estabelecido. Faz-se necessário estar aberto ao diálogo e às considerações diferentes, pois na mesma Bíblia, dependendo da abordagem, pressupostos, espaço-tempo e subjetivismo, podem surgir diferentes interpretações. Não é aconselhável considerar o diferente errado, mas apenas diferente, aprendendo a viver e conviver fraternalmente, buscando o alvo que é viver Cristo e fazê-lo conhecido.

\section{REFERÊNCIAS}

ALMEIDA, João Ferreira de. A Bíblia Sagrada. Revista e atualizada no Brasil. 2.ed. São Paulo: Sociedade Bíblica do Brasil, 1999.

BERKHOF, Louis. A história das doutrinas cristãs. São Paulo: Publicações Evangélicas Selecionadas, 1992.

CALVINO, João. As Institutas. São Paulo: Cultura Cristã, 2006.

CULTURA CRISTÃ. Os Cânones de Dort. 3.ed. São Paulo: Cultura Cristã, 2016.

DELFSTRA, Gerrit. A doutrina da predestinação de Calvino até Armínio. Monografia apresentada para o Mestrado em Teologia, 1984.

DUDUS, Gérson. Teologia dos Reformadores. São Paulo: Vida Nova, 1994. 
FEINBERG, John; et al. Predestinação e livre-arbítrio. 3.ed. São Paulo: Mundo Cristão, 2000.

GEORGE, Timothy. Teologia dos Reformadores. São Paulo: Vida Nova, 1994.

HANKO, Herman. João Calvino: o reformador suíço. Disponível em: http:// monergismo.com/herman-hanko/joao-calvino-o-reformador-suico/. Acesso 19 Dez. 2017.

HORTON, Michael. Calvino e a vida cristã. São Paulo: Cultura Cristã, 2017.

OLSON, Roger. Teologia Arminiana: mitos e realidades. São Paulo: Reflexão, 1992.

SILVESTRE, Armando. Calvino: o potencial revolucionário de um pensamento. São Paulo: Vida, 2009.

TILLICH, Paul. Teologia Sistemática. São Paulo: Paulinas, 1984.

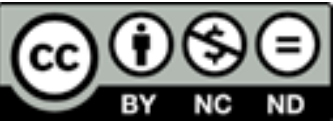

A Revista Batista Pioneira está licenciada com uma Licença Creative Commons Atribuição - Não Comercial - Sem Derivações - 4.0 Internacional 